JPH RECODE Maret 2019; 2 (2) : 117-127

http://e-journal.unair.ac.id/JPHRECODE

\title{
HUBUNGAN LOKASI AIR MINUM DENGAN INTAKE CAIRAN PADA PEKERJA TERPAPAR SUHU PANAS
}

\author{
Dedi Irwan', Indriati Paskarini ${ }^{2}$ \\ 1,2Departemen Keselamatan dan Kesehatan Kerja, Fakultas Kesehatan Masyarakat, Universitas Airlangga \\ irwandedi46@yahoo.com
}

\begin{abstract}
The workers at the processing and steaming crackers have a risk of heat exposure, it can lead dehidration when it is not balanced with adequate drinking water. The objective of the study were to analyze the correlation between drinking water location with water intake due to heat exposure among workers at the processing and steaming crackers of UD. Sumber Barokah Sidoarjo. This was an observational study with cross sectional approach. The population of this study by number of 27 workers at the processing and steaming crackers. Variables examined are respondent characteristics, activity / physical, drinking water location, water intake and work climate. Data were analyzed descriptively and presented in the form of cross tabulation. The results showed that 44.44\% of respondents from 21-34 years old. Highest educational level was high school. All respondents has work experience between 1-4 years. Drinking water location $>3$ meters. Most respondents drink more than 8 times with water consumption between 3.2 to 4.8 liters. WBGT (Wet Bulb Globe Temperature) value in processing and steaming section is $31,4^{0}$ C. Contingency coefficient value 0,641. Based on the result of the study above, there is correlation between drinking water location with water intake of respondents. The factory are advised to provide reachable drinking water and the workers consuming drinking water of 1 cup (200$300 \mathrm{cc}$ ) every 30 minutes.
\end{abstract}

Keywords: drinking water location, water intake, heat exposure

\begin{abstract}
ABSTRAK
Pekerja pada bagian pengolahan dan pengukusan kerupuk memiliki risiko terpapar panas, sehingga dibutuhkan konsumsi air minum yang cukup untuk mencegah terjadinya dehidrasi. Tujuan dari penelitian ini adalah mempelajari hubungan lokasi (tempat penyediaan) air minum dengan intake cairan pada pekerja terpapar panas di bagian pengolahan dan pengukusan kerupuk UD. Sumber Barokah Sidoarjo. Penelitian ini termasuk penelitian observasional dengan pendekatan cross-sectional. Populasi dari penelitian ini adalah pekerja di bagian pengolahan dan pengukusan kerupuk UD. Sumber Barokah, Sidoarjo. Sampel yang diteliti adalah total populasi dengan jumlah 27 orang pekerja. Variabel yang diteliti antara lain karakteristik responden, aktivitas/kerja fisik, lokasi air minum, intake cairan dan iklim kerja. Data yang diperoleh dianalisis secara deskriptif dan disajikan dalam bentuk tabulasi silang. Hasil penelitian menunjukkan bahwa 44,44\% responden berusia 21-34 tahun. Tingkat pendidikan tertinggi adalah tamat SMA. Seluruh responden memiliki masa kerja 1-4 tahun. Sebagian lokasi air minum dengan jarak > 3 meter dari pekerja. Frekuensi minum responden paling banyak adalah lebih dari 8 kali dengan konsumsi air minum antara 3,2 - 4,8 liter. Nilai ISBB (Indeks Suhu Basah dan Bola) di bagian pengolahan dan pengukusan sebesar $31,4^{\circ} \mathrm{C}$. Nilai contingency coefficient sebesar 0,641. Berdasarkan hasil penelitian di atas, diketahui bahwa terdapat hubungan yang kuat antara jarak tempat air minum dengan intake cairan pekerja. Disarankan pengelola pabrik untuk menambah dan mendekatkan tempat air minum pada tempat bekerja, konsumsi air minum pekerja minimal 1 gelas $(200-300 \mathrm{cc})$ setiap 30 menit.
\end{abstract}

Kata kunci: lokasi air minum, intake cairan, paparan panas 
Dedi et al. Hubungan Lokasi Air Minum Dengan Intake Cairan Pada Pekerja Terpapar Suhu Panas
JPH RECODE Maret 2019; 2 (2) : 117-127 http://e-journal.unair.ac.id/JPHRECODE

\section{PENDAHULUAN}

Undang-undang Nomor 13 Tahun 2003 tentang Ketenagakerjaan di Indonesia menjadi penekanan bagi undang-undang sebelumnya yang menegaskan peranan dan kedudukan tenaga kerja sebagai pelaku pembangunan (Presiden Republik Indonesia, 2003). Dalam hal ini perlu diperhatikannya keselamatan dan kesehatan para tenaga kerja karena sudah menjadi hakbagi tenaga kerja untuk mendapatkan perlindungan guna meningkatkan kualitas dan kesejahteraan tenaga kerja. Hal serupa juga dijelaskan pada Konvensi ILO (Internasional Labour Organization) nomor 120 yang telah disetujui tentang Higiene dalam perniagaan dan kantor-kantor dan undang-undang tentang Pokok-Pokok tenaga kerja yang memuat pasal-pasal tentang higiene perusahaan dan kesehatan kerja (Suma'mur, 2014).

Faktor yang berpengaruh terhadap kesehatan pekerja meliputi gangguan kesehatan pada pekerja, penyakit akibat kerja, gizi kerja serta faktor-faktor fisis yang mempengaruhi terjadinya masalah pada kesehatan pekerja. Khususnya pada masalah gangguan kesehatan dan penyakit akibat kerja. Hal tersebut kurang mendapat perhatian karena hubungan antara penyakit dengan pekerjaan sering kali tidak terdeteksi, dikarenakan gejala yang timbul sangat mirip dengan penyakit pada umumnya dan masa laten penyakit akibat kerja biasanya sangat lama (Harrianto, 2008).

Gangguan kesehatan yang dialami pekerja dapat muncul karena berbagai macam faktor, diantaranya adalah kurangnya intake cairan atau konsumsi air minum oleh pekerja. Penyediaan air minum dari perusahaan atau pengelola sangat penting bagi pekerja untuk memenuhi kebutuhan cairan selama bekerja.

Lokasi air minum merupakan jarak antara tempat penyediaan air minum dengan tempat responden bekerja. NIOSH (2011) menyarankan agar lokasi tempat air minum dapat dengan mudah terjangkau oleh pekerja. Lokasi tempat air minum yang dekat dan terjangkau dapat meningkatkan konsumsi air minum dari pekerja baik frekuensi maupun volume atau jumlah air minum. Peningkatan konsumsi air minum akan meminimalkan risiko pekerja untuk terkena dehidrasi.

Intake cairan merupakan pemenuhan kebutuhan cairan dalam tubuh dengan mengkonsumsi air minum. Semakin jauh jarak tempat air minum dengan tempat bekerja akan menimbulkan kesulitan pada pekerja untuk memenuhi kebutuhan konsumsi air minum. Pekerja akan cenderung lebih malas untuk mengambil air minum pada jarak yang tidak terjangkau (Xiang et al., 2015).

Pekerja yang bekerja pada paparan suhu panas dan mengkonsumsi air minum dalam jumlah yang kurang akan berisiko lebih besar terkena dehidrasi karena jumlah cairan yang berkurang di dalam sistem metabolisme tubuh (Jayasumana et al., 2015). Salah satu penelitian yang menunjukkkan bahwa adanya pengaruh iklim kerja juga akan mempengaruhi dehidrasi (Puspita dan Noeroel , 2017).

Pekerja yang mengalami dehidrasi akan berpengaruh pada kondisi kesehatan dan produktivitas dalam bekerja. Dehidrasi apabila dibiarkan terus menerus akan menyebabkan kegagalan fungsi tubuh dalam mempertahankan kondisi yang normal. Tubuh tidak akan mampu menahan kondisi tersebut dalam waktu yang lama sehingga akan menyebabkan keluhan kesehatan (Harrianto, 2008).

Kondisi dehidrasi dan iklim kerja yang panas menambah risiko pada pekerja. Keluhan kesehatan yang dialami oleh pekerja akan menyebabkan penyakit kerja akibat kurangnya konsumsi air minum atau cairan dalam tubuh pekerja. Dehidrasi (kekurangan cairan) ini akan terjadi di jaringan maupun sel tubuh dan ditandai dengan kulit yang menjadi keriput, turgor menurun, mulut dan lidah kering dan mata cowong. Oleh karena itu, orang yang bekerja di lingkungan panas sebaiknya minum cukup air. NIOSH (2011) menganjurkan agar orang yang bekerja di tempat panas minum 200$300 \mathrm{cc} / 30$ menit tanpa menunggu timbulnya rasa haus.

Salah satu faktor yang mengakibatkan penyakit akibat kerja adalah faktor iklim kerja yang terlalu tinggi maupun terlalu rendah. Karena apabila tidak sesuai dengan kondisi suhu tubuh pekerja dapat menyebabkan suhu lingkungan menjadi ekstrem.

Hal yang paling menentukan dalam kenyamanan kerja yaitu iklim kerja yang merupakan kombinasi dari suhu udara, kelembaban, kecepatan aliran udara dan panas radiasi. Pekerja yang bekerja di lingkungan panas 
harus menanggung panas badan yang terbentuk sebagai hasil aktifitas kerja fisik, di samping itu juga mendapat beban tambahan berupa panas yang ditimbulkan dari proses kerjanya (Suma'mur, 2014).

Tubuh mengalami metabolisme untuk menghasilkan energi yang disertai dengan pertukaran panas dari lingkungan sekitar. Hal ini dapat mempertahankan suhu tubuh manusia menjadi tetap karena terjadi keseimbangan antara panas yang dihasilkan dalam tubuh dengan panas lingkungan. Mekanisme pertukaran panas bisa secara konduksi, konveksi, radiasi dan evaporasi. Akibat dari suhu lingkungan yang ekstrem panas, seorang individu akan merasa tidak nyaman, menimbulkan rasa cepat lelah, mengantuk, berkurangnya penampilan kerja, dan meningkatnya kemungkinan kesalahan kerja (Harrianto, 2008).

Seorang pekerja yang terpapar karena iklim kerja yang panas tanpa suatu peralatan khusus tentu akan terganggu daya tahan tubuhnya dan mengatasi panas dengan cara berkeringat sehingga menimbulkan kehilangan cairan tubuh. Pemberian air minum merupakan cara yang bertujuan untuk menggantikan cairan tubuh yang hilang, sehingga cairan tubuh dalam keadaan seimbang. Banyaknya cairan tubuh dan garam yang keluar melalui keringat dapat mempengaruhi performa kerja seseorang. Jika air yang keluar melalui keringat ini tak ditukar dengan minum yang cukup maka akan terjadi dehidrasi (Suma'mur, 2014).

Pabrik kerupuk merupakan salah satu usaha sektor informal yang melibatkan suhu tinggi dalam proses produksinya. Berdasarkan data penelitian dari Fadhilah (2014), didapatkan hasil pengukuran suhu lingkungan yang dilakukan pada 3 titik di 2 pabrik kerupuk di kecamatan Ciputat Timur masing-masing adalah $32,4^{\mathrm{O}} \mathrm{C}, 33,6^{\mathrm{O}} \mathrm{C}$ dan $32,1^{\mathrm{O}} \mathrm{C}$. Hasil pengukuran tersebut menunjukkan bahwa semua titik pengukuran melebih NAB (Nilai Ambang Batas) iklim kerja yang diatur dalam Permenaker No. 13

Tahun 2011 yaitu sebesar $28^{\mathrm{O}} \mathrm{C}$ untuk beban kerja sedang (Menteri Tenaga Kerja dan Transmigrasi, 2011). Dengan adanya sumber panas dari lingkungan kerja dan penurunan cairan tubuh akan berpengaruh terhadap kesehatan pekerja, apabila dibiarkan terus- menerus dalam waktu yang lama akan menimbulkan keadaan yang lebih buruk.

Panas yang ada di lingkungan industri seringkali melebihi panas yang ada di lingkungan umum. Pekerjaan yang dilakukan di lingkungan panas dapat dikategorikan sebagai pekerjaan dengan beban berat karena lebih banyak memerlukan energi. Panas dari lingkungan kerja ditambah dengan panas akibat metabolisme tubuh dapat melampaui kapasitas fisiologi pekerja sehingga dapat mengganggu proses pengaturan suhu tubuh dan akibatnya kinerja menjadi turun selanjutnya dapat muncul tanda-tanda terkena stress panas.

UD.Sumber Barokah merupakan industri yang bergerak dalam produksi kerupuk yang berasal dari bahan tepung terigu. Kegiatan produksi tersebut memerlukan panas yang tinggi terutama pada saat pengolahan dan pengukusan kerupuk yang bisa menimbulkan panas di tempat kerja. Kemungkinan pekerja terpapar panas di lingkungan kerjanya dan rentan terhadap dehidrasi apabila pekerja kurang dalam mengkonsumsi air minum.

Berdasarkan hal tersebut, maka tujuan dari penelitian ini adalah untuk mengetahui hubungan antara lokasi (tempat penyediaan) air minum dengan intake cairan dari pekerja yang terpapar panas di industri kerupuk UD. Sumber Barokah Sidoarjo.

\section{METODE}

Penelitian ini termasuk pada jenis penelitian observasional. Rancang bangun penelitian ini menggunakan penelitian deskriptif dengan pendekatan Cross Sectional dimana pengambilan data dilakukan sekali waktu pada saat yang bersamaan.

Populasi pada penelitian ini adalah karyawan bagian pengolahan dan pengukusan kerupuk UD. Sumber Barokah tang berjumlah 27 orang. Sampel pada penelitian ini adalah total dari populasi yang berjumlah 27 orang. Penelitian dilakukan di bagian pengolahan dan pengukusan pabrik kerupuk UD. Sumber Barokah desa Klagen RT 01 RW 04, Krian, Sidoarjo pada bulan Oktober 2015.

Variabel pada penelitian ini meliputi karakteristik responden (umur, pendidikan, masa kerja), aktifitas/kerja fisik responden, lokasi air minum, penyediaan air minum, intake cairan 
(frekuensi minum, kuantitas air minum) dan iklim kerja.

Teknik pengumpulan data primer dilakukan dengan observasi dan kuesioner langsung kepada responden dan observasi pada fasilitas yang terdapat di pabrik sebagai sarana bagi pekerja. Pengukuran iklim kerja di lingkungan tempat kerja dengan menggunakan heat stress monitoring dengan merk

Questemp ${ }^{o} 36$ Thermal Environment Monitor.

Pengukuran iklim kerja pada bagian pengolahan dan pengukusan kerupuk dilakukan sebanyak 3 kali kemudian hasilnya dirata-rata.

Untuk menguji hubungan variabel lokasi air minum dengan intake cairan pekerja yang Tabel 1. Distribusi umur responden bagian pengolahan dan pengukusan kerupuk Oktober 2015.

\begin{tabular}{|c|c|c|}
\hline Umur & Jumlah & Persentase (\%) \\
\hline$\leq \mathbf{2 0}$ tahun & 7 & 25,93 \\
$\mathbf{2 1 - 3 4}$ tahun & 12 & 44,44 \\
$\mathbf{3 5}-\mathbf{5 0}$ tahun & 6 & 22,22 \\
$\mathbf{2 5 1}$ tahun & 2 & 7,41 \\
\hline Total & 27 & 100 \\
\hline
\end{tabular}

\section{Karakteristik Pekerja Menurut Tingkat Pendidikan}

Dalam penelitian ini tingkat pendidikan dibagi menjadi tiga, yaitu SD, SMP dan SMA. Tingkat pendidikan paling banyak dari responden Tabel 2. Distribusi umur responden di bagian pengolahan dan pengukusan kerupuk Oktober 2015.

\begin{tabular}{|c|c|c|}
\hline Pendidikan & Jumlah & Persentase $(\%)$ \\
\hline Tamat SD & 6 & 22,22 \\
\hline Tamat SMP & 17 & 62,96 \\
\hline Tamat SMA & 4 & 14,82 \\
\hline Total & 27 & 100 \\
\hline
\end{tabular}

Karakteristik Pekerja Menurut Masa Kerja

Masa kerja adalah lama waktu responden bekerja di pabrik kerupuk sampai dilakukannya penelitian. Sebagian besar responden memiliki Tabel 3. Distribusi responden menurut masa kerja Oktober 2015

\begin{tabular}{|c|c|c|}
\hline Masa kerja & Jumlah & Persentase (\%) \\
\hline$\leq \mathbf{1}$ tahun & 5 & 18,5 \\
$\mathbf{1 - 2}$ tahun & 12 & 44,44 \\
\hline
\end{tabular}


Lanjutan

Tabel 3. Distribusi responden menurut masa kerja Oktober 2015

\begin{tabular}{|c|c|c|}
\hline Masa kerja & Jumlah & Persentase (\%) \\
\hline $2-3$ tahun & 6 & 22,22 \\
$>3$ tahun & 4 & 14,8 \\
\hline Total & 27 & 100 \\
\hline
\end{tabular}

Sumber: data primer

\section{Aktifitas/Kerja Fisik Responden}

Aktifitas/kerja fisik dari seluruh responden yang diteliti meliputi aktifitas pengolahan dan pengukusan kerupuk di pabrik kerupuk UD. Sumber Barokah Sidoarjo.

Seluruh responden yang berjumlah 27 orang pada bagian pengolahan dan pengukusan melakukan aktivitas mulai dari mencampur bahan baku kerupuk berupa tepung dengan bahan bahan lain maupun bumbunya. Setelah adonan kerupuk sudah selesai kemudian dilakukan pencetakan kerupuk dengan alat yang tersedia dan kerupuk dimasukkan ke dalam pengukusan untuk proses pematangan dan oven untuk pengeringan.

Dalam proses pengolahan kerupuk mulai dari penimbangan tepung, mencampur bumbu, membuat adonan membutuhkan waktu kurang lebih 48 menit. Untuk proses pengukusan Tabel 4. Distribusi lokasi air minum responden Oktober 2015

\begin{tabular}{|c|c|c|}
\hline Lokasi air minum (meter) & Jumlah & Persentase (\%) \\
\hline$<3$ & 18 & 66,7 \\
$>\mathbf{3}$ & 9 & 33,3 \\
\hline Total & 27 & 100 \\
\hline
\end{tabular}

\section{Penyediaan Air Minum}

Fasilitas air minum untuk konsumsi air minum pekerja di bagian pengolahan dan pengukusan kerupuk UD. Sumber Barokah sudah disediakan oleh pemilik dan pengelola pabrik.

Sumber air minum yang disediakan berasal dari air PDAM yang telah dimasak dan air mineral dalam galon yang siap minum. Penyediaan air minum diberikan setiap harinya untuk seluruh pekerja pabrik yang berjumlah 100 orang. Jumlah atau volume air yang disediakan oleh pabrik untuk seluruh karyawan dapat mencapai sekitar 900 liter setiap harinya.

Pihak pemilik pabrik juga menyediakan kran air siap minum untuk memudahkan distribusi air minum pada pekerja. Kran air siap kerupuk mulai dari memasukkan kerupuk ke pengukusan, menjaga dan mengatur suhu pengukusan, mengeluarkan kerupuk dari pengukusan, memasukkan kerupuk ke oven pengeringan dan mengeluarkan kerupuk dari oven membutuhkan waktu sekitar 45 menit.

\section{Lokasi Air Minum}

Lokasi air minum adalah jarak tempat air minum disimpan dengan tempat bekerja. Berdasarkan hasil pengamatan atau observasi yang dilakukan di bagian pengolahan dan pengukusan kerupuk UD. Sumber Barokah, diketahui bahwa lokasi tempat menyimpan air minum terdapat pada tiap bagian dengan jarak kurang dari 3 meter dan lebih dari 3 meter dari tempat karyawan bekerja. minum ini berasal dari proses air PDAM yang telah dimasak terlebih dahulu kemudian disalurkan dengan bantuan pipa yang terpasang pada alat pemasak air.

\section{Konsumsi Air Minum Responden Frekuensi Konsumsi Air Minum}

Frekuensi minum adalah kekerapan tenaga kerja mengkonsumsi air minum selama bekerja atau pada waktu istirahat. Hasil yang didapatkan pada penelitian menunjukkan bahwa sebagian besar responden mengkonsumsi air minum lebih dari 8 kali. Berikut ini merupakan hasil distribusi frekuensi minum responden. 
Tabel 5. Distribusi frekuensi konsumsi air minum responden Oktober 2015.

\begin{tabular}{|c|c|c|}
\hline Frekuensi minum & Jumlah & Persentase (\%) \\
\hline $\mathbf{4 - 8}$ kali & 9 & 33,3 \\
$>\mathbf{8}$ kali & 18 & 66,7 \\
\hline Total & 27 & 100 \\
\hline
\end{tabular}

\section{Kuantitas Air Minum}

Kuantitas air minum adalah total pemasukan air minum ke dalam tubuh selama bekerja ataupun pada waktu istirahat.

Pada penelitian yang dilakukan pada bagian pengolahan dan pengukusan kerupuk ini didapatkan hasil masih terdapat sebagian responden yang mengkonsumsi air minum kurang dari 3,2 liter selama responden bekerja.

Tabel 6. Distribusi kuantitas air minum responden Oktober 2015.

\begin{tabular}{|c|c|c|}
\hline Kuantitas air minum & Jumlah & Persentase (\%) \\
\hline$<\mathbf{3 , 2}$ liter & 9 & 33,3 \\
$\mathbf{3 , 2}-\mathbf{4 , 8}$ liter & 14 & 51,9 \\
$>\mathbf{4 , 8}$ liter & 4 & 14,8 \\
\hline Total & 27 & 100 \\
\hline
\end{tabular}

Hasil Pengukuran Iklim Kerja di Bagian Pengolahan dan Pengukusan Kerupuk UD. Sumber Barokah

Pengukuran iklim kerja dilaksanakan dengan menggunakan instrument digital berupa Heat Stress Monitoring dengan merk Questemp $36^{\circ}$ Thermal Environment Monitor, sehingga hasil yang didapat segera langsung diketahui. Pengukuran ini mengambil tempat di bagian pengolahan dan pengukusan kerupuk. Hasil pengukuran iklim kerja di pabrik kerupuk ini meliputi pengukuran suhu kering, suhu basah, suhu bola, kelembapan, kecepatan aliran udara dan indeks suhu basah dan bola.

Tabel 7. Hasil pengukuran iklim kerja bagian pengolahan dan pengukusan Oktober 2015.

\begin{tabular}{|c|c|c|c|c|c|c|}
\hline Pengukuran & $\begin{array}{c}\text { Suhu kering } \\
\left({ }^{0} \mathrm{C}\right)\end{array}$ & $\begin{array}{c}\text { Suhu } \\
\text { basah }\left({ }^{0} \mathrm{C}\right)\end{array}$ & $\begin{array}{c}\text { Suhu bola } \\
\left({ }^{0} \mathrm{C}\right)\end{array}$ & $\begin{array}{c}\text { Kelembapan } \\
(\%)\end{array}$ & $\begin{array}{l}\text { Aliran udara } \\
\text { (m/detik) }\end{array}$ & $\begin{array}{c}\text { ISBB } \\
\left({ }^{0} \mathrm{C}\right)\end{array}$ \\
\hline 1. & 32,8 & 26,7 & 36,7 & 53 & \multirow{4}{*}{$0,2-3$} & 29,7 \\
\hline 2. & 37,1 & 30,6 & 39,7 & 47 & & 33,1 \\
\hline 3. & 34,9 & 28,3 & 38,4 & 51 & & 31,33 \\
\hline Rata-rata & 34,9 & 28,5 & 38.3 & 50 & & 31.4 \\
\hline
\end{tabular}

Pengukuran di pabrik kerupuk ini termasuk kategori pengukuran di dalam ruangan karena tepat pengukuran berada di dalam, sehingga rumus yang dipakai untuk menentukan indeks suhu basah dan bola di dalam ruangan adalah:

Pengukuran ISBB pabrik kerupuk ini termasuk kategori pengukuran di dalam ruangan sehingga rumus yang dipakai untuk menentukan indeks suhu basah dan bola di dalam ruangan adalah:

ISBB dalam ruangan : $0,7 \mathrm{Sba}+0,3 \mathrm{Sg}$ Pengukuran ISBB diambil sebanyak 3 kali dengan hasil sebagai berikut: 


\section{Hubungan Lokasi Air Minum dengan Intake \\ Cairan Responden}

Berikut ini distribusi lokasi air minum dengan intake cairan dari responden.

Tabel 8. Distribusi responden berdasarkan lokasi air minum yang dikonsumsi dengan intake cairan Oktober 2015.

\begin{tabular}{|c|c|c|c|c|c|c|}
\hline \multirow{2}{*}{$\begin{array}{c}\text { Lokasi air minum } \\
\text { (meter) }\end{array}$} & \multicolumn{6}{|c|}{ Intake cairan (liter) } \\
\cline { 2 - 7 } & \multicolumn{2}{|c|}{$<3,2$} & \multicolumn{2}{|c|}{$3,2-4,8$} & \multicolumn{2}{c|}{$>4,8$} \\
\cline { 2 - 7 } & $\mathrm{N}$ & $\%$ & $\mathrm{~N}$ & $\%$ & $\mathrm{~N}$ & $\%$ \\
\hline$<3$ & 1 & 5,6 & 13 & 72,2 & 4 & 22,2 \\
$>\mathbf{3}$ & 8 & 88,9 & 1 & 11,1 & 0 & 0 \\
\hline Total & 9 & 33,3 & 14 & 51,9 & 4 & 14,8 \\
\hline
\end{tabular}

Responden yang berada pada jarak lebih dari 3 meter dengan lokasi air minum memiliki kemungkinan sebesar $88,9 \%$ untuk mengkonsumsi air minum kurang dari 3,2 liter selama bekerja. Untuk mengetahui kuat hubungan antar variabel, didapatkan nilai contingency coefficient sebesar 0,641.

\section{PEMBAHASAN}

\section{Karakteristik Responden}

Umur responden

Responden dengan golongan umur terbanyak antara 21-34 tahun $(44,44 \%)$ dan golongan umur paling sedikit adalah responden yang memiliki umur lebih dari 50 tahun $(7,41 \%)$. Bertambahnya usia seseorang dan penuaan yang dialami menyebabkan kelenjar keringat menjadi lemah sehingga mengurangi efektifitas pengontrolan suhu tubuh, hal ini dikarenakan pengeluaran atau produksi keringat sebagai respon terhadap panas terganggu yang disebabkan melemahnya kelenjar keringat pada tubuh (NIOSH, 2011).

Proses tubuh dalam mengeluarkan keringat terjadi lebih cepat pada golongan usia muda sehingga lebih rentan terjadinya kehilangan cairan tubuh melalui keringat. Menurut Soetjipto (2007) pada orang dewasa memerlukan asupan air minum minimal sebanyak 1,5-2 liter pehari dan pada usia lanjut volume air tubuh total sudah menurun dan meningkatnya pemekatan urine sehingga konsumsi air minum yang optimal untuk kelompok ini adalah 1-1,5 liter perhari.

\section{Tingkat pendidikan responden}

Pendidikan merupakan proses peningkatan kemampuan, potensi serta kapabilitas manusia yang dipengaruhi oleh kebiasaan yang baik sehingga dapat digunakan untuk diri sendiri maupun menolong orang lain untuk mencapai tujuan (Suwarno, 2006).

Mayoritas responden penelitian pada bagian pengolahan dan pengukusan kerupuk UD. Sumber barokah memiliki tingkat pendidikan SMP $(62,96 \%)$ dan tingkat pendidikan SD $(22,22 \%)$.

Pradono dan Sulistyowati (2013), menyebutkan bahwa semakin rendah tingkat pendidikan akan semakin sulit untuk mengikuti petunjuk, sedangkan semakin tinggi tingkat pendidikan maka akan semakin mudah menerima informasi. Pendidkan merupakan salah satu sarana atau media untuk mengubah perilaku seseorang agar sesuai dengan norma hidup sehat.

\section{Masa kerja responden}

Masa kerja merupakan periode waktu yang dihitung pada pertama kali pekerja melakukan aktifitas pekerjaan sampai saat penelitian berlangsung.

Ketika melakukan aktivitas fisik selama bekerja maka akan menghasilkan energi panas. Apabila energi panas tersebut tidak dikeluarkan dari tubuh maka akan membahayakan karena akan meningkatkan suhu tubuh. Pengeluaran panas dari tubuh dapat melalui berbagai macam mekanisme yaitu penguapan air dari kulit dan saluran pernafasan. Sehingga seseorang mengalami pengeluaran panas yang berlebihan maka dapat mengalami dehidrasi. Dapat 
disimpulkan bahwa, seorang pekerja yang melakukan aktivitas fisik berat maka suhu dalam tubuh akan meningkat yang menimbulkan peningkatan suhu pada tubuh sehingga dapat membahayakan kesehatan (Kementerian Kesehatan Republik Indonesia, 2014).

Aklimatiasi merupakan suatu proses yang bertahap dan memerlukan waktu beberapa hari untuk menyesuaikan tubuh dengan suhu ekstrim lingkungan. Seseorang yang pertama kali bekerja pada suhu lingkungan yang esktrim maka suhu dalam tubuh akan meningkat, denyut nadi meningkat, dan timbul rasa ketidaknyamanan seperti rasa lelah. Selama proses tersebut, tubuh akan mengeluarkan keringat sehingga suhu panas dalam tubuh akan berkurang. Perubahan fisiologis yang terjadi dalam tubuh melalui adanya proses aklimitasi tersebut dapat menurunkan denyut jantung. Proses aklimatisasi tersebut juga membantu untuk mempercepat pengeluaran keringat dan konsentrasi garam dalam keringat menurun (NIOSH, 2011).

Harrianto (2008) menyatakan bahwa tingkat pengalaman kerja seseorang dalam bekerja akan mempengaruhi terjadinya keluhan selama bekerja. Orang yang mempunyai pengalaman kerja akan mampu bekerja secara efisien, dapat mengatur besarnya tenaga yang dikeluarkan selama bekerja. Pekerja dengan pengalaman kerja lebih lama juga akan mengetahui posisi yang nyaman untuk dirinya sehingga dapat mengurangi terjadinya keluhan selama bekerja.

\section{Lokasi air minum}

Lokasi air minum pada bagian pengolahan dan pengukusan kerupuk mempunyai jarak antara 1-7 meter dari tempat karyawan bekerja. Hal ini menunjukkan bahwa lokasi penempatan air minum di pabrik kerupuk ini pada sebagian responden tidak mudah dijangkau karena membuat tenaga kerja mengkonsumsi air minum dengan meninggalkan pekerjaannya.

Apabila lokasi air minum tidak mudah dijangkau dapat menyebabkan tenaga kerja malas untuk mengkonsumsi air minum sesuai dengan anjuran 200-300 cc per 30 menit, sehingga terjadi pengeluaran keringat secara terus menerus tanpa penggantian cairan yang hilang. Akibatnya timbul kelelahan yang lebih dini karena terjadi penurunan dalam aliran darah yang menuju otot aktif, otak dan organ dalam lain.

Menurut Soeripto (2008) air minum sebaiknya disimpan di tempat dingin dan ditempatkan dekat dengan tempat kerja sehingga tenaga kerja dapat mengambil tanpa meninggalkan lingkungan tempat kerja sebab hal ini dapat berpengaruh terhadap frekuensi tenaga kerja dalam mengkonsumsi air minum.

\section{Penyediaan air minum bagi responden}

Jumlah air dalam tubuh sebanyak $45 \%$ $70 \%$ dari berat badan. Asupan air yang dibutuhkan tubuh sebanyak 2,5 liter per harinya yang terdiri dari minuman sebanyak 1,2 liter, makanan 1 liter dan dari metabolisme air dalam tubuh didapatkan 0,3 liter. Sedangkan air yang keluar dari tubuh berasal dari ginjal, kulit, paru, usus sebanyak 1,5-2 liter perharinya (Soetjipto, 2007).

Kebutuhan akan air minum bagi pekerja yang terpapar panas di pabrik kerupuk ini berguna untuk menyeimbangkan cairan dalam tubuh. Air minum yang disediakan oleh pengelola adalah air putih yang berasal dari proses pemasakan air PDAM melalui ketel yang kemudian didistribusikan melalui saluran serta kran air yang siap minum dan penyediaan air minum dengan air mineral dalam galon.

Apabila air minum yang disediakan tidak mencukupi kebutuhan tenaga kerja maka akan menurunkan produktivitas tenaga kerja dalam bekerja karena terjadi penurunan kesiagaan, akurasi pekerjaan, kapasitas mental dan juga pemahaman informasi yang dapat membahayakan tenaga kerja akibat kurangnya mengkonsumsi air minum.

\section{Intake Cairan Responden Frekuensi minum responden}

Sebagian besar pekerja mengkonsumsi air minum lebih dari 8 kali selama bekerja, hal tersebut sangat penting karena mengkonsumsi air minum tanpa menunggu rasa haus akan menjaga keseimbangan dan jumlah cairan dalam tubuh. Pekerja yang mengkonsumsi air minum dengan menunggu rasa haus terlebih dahulu akan menyebabkan menurunnya cairan dalam tubuh sehingga menimbulkan ketidaknyamanan selama bekerja. 
Xiang et al (2015) menyatakan bahwa pekerja pada tempat yang terpapar suhu panas sebaiknya meningkatkan frekuensi konsumsi air minum tanpa menunggu timbulnya rasa haus dengan tujuan supaya cairan tubuh tetap dalam keadaan seimbang.

\section{Kuantitas air minum responden}

Sebanyak $9 \quad(33,3 \%)$ responden mengkonsumsi air minum kurang dari 3,2 liter, hal ini menunjukkan masih ada sebagian responden yang masih kurang dalam mengkonsumsi air minum. Bagi pekerja yang masih kurang dalam mengkonsumsi air minum dapat mengakibatkan terjadinya dehidrasi.

Pada orang dengan dehidrasi berat, volume cairan ekstrasel akan turun sehingga cairan intrasel akan pindah ke ekstrasel. Intrasel akan mengalami dehidrasi yang ditandai dengan munculnya rasa haus, selain itu keseimbangan ion akan terganggu (Soetjipto, 2007).

NIOSH (2011) menganjurkan bagi orang yang bekerja di tempat dengan paparan suhu panas untuk mengkonsumsi air minum sebanyak 200-300 cc/30 menit tanpa menunggu timbulnya rasa haus agar tidak terjadi dehidrasi.

\section{Pengukuran iklim kerja}

Menurut Peraturan Menteri Tenaga Kerja dan Transmigrasi No.13 tahun 2011, iklim kerja adalah hasil perpaduan antara suhu, kelembaban, kecepatan gerakan udara dan panas radiasi dengan tingkat pengeluaran panas dari tubuh tenaga kerja sebagai akibat pekerjaannya, yang dimaksudkan dalam peraturan ini adalah iklim kerja panas (Presiden Republik Indonesia, 2003). Untuk mengetahui kondisi lingkungan kerja dikatakan nyaman atau tidak nyaman, maka diperlukan pengukuran iklim kerja di tempat kerja yang terpapar panas yang bertujuan untuk mengetahui kondisi lingkungan kerja berdasarkan suhunya.

Suhu dalam tubuh harus dalam kondisi stabil yaitu antara panas yang masuk dan keluar. Suhu panas dalam tubuh terjadi karena lingkungan eksternal yang ekstrim dan juga produksi panas internal dari proses metabolik. Proses kompensatorik dalam tubuh sangat diperlukan untuk mempertahankan tubuh dalam kondisi stabil. Pertukaran panas dalam tubuh melalui proses radiasi, konduksi, konveksi, dan evaporasi. Berkeringan merupakan proses terjadinya evaporasi aktif dibawah kendali saraf simpatis. Mengurangi kadar panas evaporatif dalam tubuh dapat terjadi karena bekeringat. Hal tersebut merupakan mekanisme homeostatik penting dalam tubuh (Guyton, 2012).

Pada dasarnya ketika suhu lingkungan lebih tinggi daripada tubuh maka tubuh akan berkeringat. Hal ini diperlukan untuk mengurangi suhu tubuh yang meningkat. Keringat merupakan larutan garam yang secara aktif dikeluarkan oleh tubuh melalui kelenjar keringat (Guyton, 2012).

Kondisi iklim kerja dapat diperoleh dari hasil pengukuran dengan alat digital yang secara otomatis akan menunjukkan hasil secara langsung tanpa melalui rumus perhitungan ISBB. Hasil pengukuran pada bagian pengolahan dan pengukusan diperoleh $31,4^{\circ} \mathrm{C}$ dengan beban kerja yang masuk dalam kategori sedang, ISBB pada bagian ini telah melewati NAB ISBB yang diperkenankan yaitu sebesar $28{ }^{\circ} \mathrm{C}$.

Berdasarkan Peraturan Menteri Tenaga Kerja dan Transmigrasi No.13 tahun 2011 tentang nilai ambang batas faktor fisika dan faktor kimia di tempat kerja, ISBB yang berada di atas NAB dapat dilakukan pengaturan waktu kerja dan istirahat menurut tingkat beban kerja (Menteri Tenaga Kerja dan Transmigrasi, 2011). Dengan catatan beban kerja ringan membutuhkan 200 kilo kalori/jam, beban kerja sedang membutuhkan lebih dari 200 sampai dengan kurang dari 350 kilo kalori/jam, dan beban kerja berat membutuhkan lebih dari 350 sampai dengan kurang dari 500 kilo kalori/jam.

Pada dasarnya tubuh akan mengalami homeostatis untuk mempertahankan suhu tubuh dalam menjaga metabolisme sel. Ketika tubuh mengalami peningkatan suhu, meskipun dalam kadar yang sedikit hal itu dapat menyebabkan gangguan pada fungsi syaraf dan kerusakan protein tetap. Suhu inti tubuh diantaranya organorgan abdomen seperti thoraks, sistem saraf pusat, dan otot rangka memiliki suhu yang pada dasarnya konstan yaitu $37,8^{\circ} \mathrm{C}$. Suhu pada organoragan tersebut harus tetap stabil dalam kondisi apapun. Hal ini bebeda dengan suhu kulit yang selalu berubah-ubah dan umunya cenderung dingin. Suhu kulit yang berubah-ubah ini bertujuan untuk memonitor pertahanan suhu tubuh agar tetap stabil. Nilai tubuh yang tetap stabil ini terjadi karena adanya mekanisme 
termoregularik yang dikoordinasikan oleh hipotalamus (Guyton, 2012).

Dampak dari iklim kerja yang melebihi NAB yaitu berupa keluhan seperti cepat lelah, kejang otot, pusing, keringat berlebih, mual, gatal, kulit kering, badan panas, dan kulit kemerahan. Keluhan yang dirasakan oleh pekerja tersebut merupakan gejala awal dari penyakit akibat kerja karena terpapar panas. Hal ini dapat diatasi dengan penanganan yang tepat pada tenaga kerja sesuai dengan jenis keluhan dan penyakit yang dialami (Harrianto, 2008).

\section{Hubungan Lokasi Air Minum dengan Intake Cairan dari Responden}

Responden yang berjarak lebih dari 3 meter dari lokasi tempat air minum sebanyak $88,9 \%$ memungkinkan hanya mengkonsumsi air minum kurang dari 3,2 liter selama bekerja. Nilai contingency coefficient yang didapatkan sebesar 0,641 yang artinya hubungan antara lokasi tempat air minum dengan intake cairan dari responden adalah kuat. Semakin jauh jarak pekerja dari lokasi air minum semakin berkurang konsumsi air minumnya, sebaliknya apabila semakin dekat jarak pekerja pada lokasi air minum akan semakin bertambah jumlah konsumsi air minumnya.

Menurut Kementerian Kesehatan Republik Indonesia (2014) pada pekerja dengan paparan suhu panas dianjurkan untuk mengkonsumsi lebih banyak air minum. Pekerja yang tidak cukup mengkonsumsi air minum selama bekerja akan lebih rentan terkena dehidrasi apabila dibiarkan akan menimbulkan keluhan yang semakin serius.

Keluhan yang disebabkan akibat terganggunya keseimbangan cairan dalam tubuh dapat menimbulkan efek yang serius terhadap kesehatan sehingga dapat memicu terjadinya penyakit akibat kerja seperti heat stroke, heat hyperpyrexia, heat syncope, heat exhaustion, heat cramps, heat rash, dan heat edema (Harrianto, 2008).

Menurut Bernard (2006), reaksi fisiologis akibat pemaparan panas yang berlebihan dapat dimulai dari gangguan fisiologis yang sangat sederhana sampai dengan terjadinya penyakit yang sangat serius, sehingga juga dapat menyebabkan penurunan berat badan.

Menurut penelitian Suwondo, et al (2008) pemeliharaan kesegaran tenaga kerja dengan pemberian air minum yang cukup sesuai dengan berat ringannya pekerjaan bermanfaat untuk mencegah dehidrasi maupun memperbaiki tekanan darah responden. Manfaat mengkonsumsi air minum dalam jumlah cukup menjadikan baik pencernaan maupun metabolisme dapat bekerja pada kapasitas maksimalnya. Sebagai tambahan, bila mendapatkan air yang cukup maka dapat memperkuat daya tahan tubuh karena air dapat menaikkan simpanan glikogen, suatu bentuk karbohidrat yang tersimpan dalam otot dan digunakan sebagai energi saat bekerja.

Salah satu fungsi utama air minum adalah untuk menstabilkan suhu tubuh. NIOSH (2011), menganjurkan agar orang yang bekerja di tempat panas minum 200-300 cc/30 menit tanpa menunggu timbulnya rasa haus. Mengkonsumsi air minum secara teratur akan membantu tingkat energi dalam mengatasi gejala dehidrasi seperti kelelahan.

Keluhan setelah bekerja perlu diperhatikan karena bisa saja hal tersebut merupakan gejala penyakit yang dapat berakibat turunnya kapasitas kerja yang pada akhirnya dapat menurunkan produktivitas kerja. Sehingga bagi pekerja yang bekerja dengan paparan suhu panas perlu memperhatikan asupan kalori secara terstruktur serta tambahan air minum sebagai pengganti cairan yang hilang selama kerja sehingga daya tahan tubuh menjadi lebih baik dan produktivitas tenaga kerja dapat ditingkatkan (Putra, 2009).

\section{KESIMPULAN}

Berdasarkankan hasil penelitian dan pembahasan dengan mengacu pada rumusan masalah dan tujuan penelitian, maka diperoleh kesimpulan bahwa mayoritas responden berumur 21 - 34 tahun $(44,44 \%)$ dengan tingkat pendidikan tertinggi yaitu tamat SMA. Masa kerja responden berkisar antara 1-4 tahun.

Pengelola pabrik menyediakan air minum untuk pekerja dengan sebagian jarak lokasi air minum lebih dari 3 meter dari tempat bekerja. Mayoritas responden mengkonsumsi air minum lebih dari 8 kali dengan jumlah air minum antara 3,2-4,8 liter.

Pengukuran ISBB pada bagian pengolahan dan pengukusan kerupuk sebesar $31,4^{\circ} \mathrm{C}$, 
sehingga UD. Sumber Barokah memiliki nilai ISBB yang melewati NAB iklim kerja.

Pekerja dengan jarak lebih dari 3 meter dari lokasi air minum cenderung akan mengkonsumsi air minum lebih sedikit dibandingkan dengan pekerja dengan jarak kurang dari 3 meter dari lokasi air minum.

Pada penelitian ini didapatkan hubungan yang kuat antara lokasi air minum dengan intake cairan pada pekerja yang terpapar suhu panas.

\section{DAFTAR PUSTAKA}

Bernard, T. 2006. TLV for Heat Stress and Strain. EOH Faculty Page. Florida:University of South Florida.

Fadhilah, R. 2014. Faktor-Faktor yang Berhubungan dengan Heat Strain pada Pekerja Pabrik Kerupuk di Wilayah Kecamatan Ciputat Timur. Universitas Islam Negeri, Syarif Hidayatullah.

Guyton, A. C. 2012. Fisiologi Manusia dan Mekanisme Penyakit. edisi revisi, EGC.

Harrianto, R. 2008. Buku Ajar Kesehatan Kerja. Jakarta : EGC.

Jayasumana C, Priyani P, Suneth A, Chintaka W, Sarath G, S. S. 2015. Drinking Well Water and Occupational Exposure Herbicides is Associated with Chronic Kidney Disease in Padavi-Sripura, Sri Lanka. BioMed Central, 14(6).

Kementerian Kesehatan Republik Indonesia. 2014. Pedoman Kebutuhan Cairan Bagi Pekerja Agar Tetap Sehat dan Produktif. Edisi 1. Direktorat Kesehatan Kerja Kementerian Kesehatan RI bekerjasama dengan Perhimpunan Spesialis Kedokteran Okupasi Indonesia . Jakarta.

Menteri Tenaga Kerja dan Transmigrasi. 2011. Peraturan Menteri Tenaga Kerja dan Transmigrasi Nomor 13/MEN/X/2011 Tentang Nilai Ambang Batas Faktor Fisika dan Kimia di Tempat Kerja.

NIOSH. 2011. Occupational Exposure to Hot Environments. DHHS Publikasi No. 86 113.

Pradono, J. dan Sulistyowati, N. 2013. Hubungan Antara Tingkat Pendidikan, Pengetahuan tentang Kesehatan Lingkungan, Perilaku Hidup Sehat dengan Status Kesehatan. Buletin Penelitian Sistem Kesehatan. Diakses https://media.neliti.com/media/publications/ 20885-ID-correlation-between-educationlevel-knowledge-of-environmental-healthhealthy-be.pdf.

Presiden Republik Indonesia. 2003. UndangUndang No.13 Tahun 2003 tentang Ketenagakerjaan.

Puspita, A. D. dan N. W. 2017. Gambaran Iklim Kerja Dan Tingkat Dehidrasi Pekerja Shift Pagi Di Bagian Injection Moulding 1 Pt.X Sidoarjo. Journal of Public Health Research and Community Health Development, 1(1), pp. 15-26.

Putra, I. D. G. A. 2009. Asupan Kalori yang Kurang Dapat Meningkatkan Beban Kerja dan Keluhan Pengrajin Gamelan di Desa Thingan Kabupaten Klungkung.

Soeripto, M. 2008. Higiene Industri. Jakarta: Balai Penerbit FKUI.

Soetjipto. 2007. Seminar Air Sehat: Water Metabolism. Surabaya: FK Universitas Airlangga.

Suma'mur. 2014. Higiene Perusahaan dan Kesehatan Kerja (HIPERKES). 2 ed. Jakarta: Sagung Seto.

Suwarno, W. 2006. Dasar-Dasar Ilmu Pendidikan. Yogyakarta:Ar-Ruzz Media.

Suwondo., Notokusuma, W., Suriadi, J. 2008. Perbedaan Tekanan Darah Pada Pekerja Yang Terpapar Panas di Industri Sale Pisang Suka Senang Kabupaten Ciamis. Jurnal Promosi Kesehatan Indonesia, 3(1), pp. 5562.

Xiang, J. et al. 2015. Perceptions of workplace heat exposure and controls among occupational hygienists and relevant specialists in Australia. PLOS ONE. doi: 10.1371/journal.pone.0135040. 